\title{
Złamania niskoenergetyczne - nowe powikłanie cukrzycy typu 2?
}

\author{
Low-energy fractures - a new complication of type 2 diabetes?
}

\section{STRESZCZENIE}

Niska masa kostna była dotychczas tradycyjnie łączona z cukrzycą typu 1. Ostatnie badania potwierdziły, że chorzy na cukrzycę typu 2 doznają złamań niskoenergetycznych częściej niż osoby zdrowe, tymczasem gęstość masy kostnej jest u nich podwyższona lub taka sama jak u osób zdrowych. Wydaje się, że ocena gęstości masy kostnej za pomocą badania densytometrycznego nie oddaje złożoności patologii tkanki kostnej u chorych na cukrzycę, co współcześnie jest przedmiotem wielu badań. Wzrost ryzyka złamania uwarunkowany jest prawdopodobnie m.in. długością trwania choroby, jej wyrównaniem metabolicznym, obecnością powikłań, rodzajem stosowanego leczenia, zwiększoną podatnością na upadki. Upośledzona jest prawdopodobnie tzw. jakość kości, co jest efektem nagromadzenia w kości zaawansowanych produktów glikacji, nieprawidłowego usieciowania kolagenu oraz niskiego tempa obrotu kostnego. Wykazano także, że u chorych na cukrzycę parametry strukturalne i geometryczne kości są gorsze. W świetle wzrastającego zagrożenia złamaniami wśród kobiet po menopauzie wskazana jest kalkulacja ryzyka złamania także wśród

Adres do korespondencji:

dr n. med. Joanna Dytfeld

Pracownia Chorób Metabolicznych Kości

Katedra i Zakład Medycyny Rodzinnej

Uniwersytet Medyczny im. Karola Marcinkowskiego

ul. Przybyszewskiego 49, 60-355 Poznań

Tel.: 48 (61) 86911 44, faks: 48 (61) 8691143

e-mail: dytfeld@poczta.onet.pl

Diabetologia Kliniczna 2015, tom 4, 3, 117-126

DOI: $10.5603 /$ DK.2015.0011

Copyright (C) 2015 Via Medica

Nadesłano: 01.04.2015

Przyjęto do druku: 15.05.2015 starszych chorych z cukrzycą typu 2. (Diabet. Klin. 2015; 4, 3: 117-126)

Słowa kluczowe: cukrzyca typu 2, osteoporoza, gęstość kości, złamania osteoporotyczne, obrót kostny

\section{ABSTRACT}

Low bone mineral density has traditionally been linked with type 1 diabetes. Latest research has confirmed that type 2 diabetics have increased fracture risk, whereas their bone mineral density is normal or increased when compared to healthy peers. It seems the assessment of bone mineral density using DXA (dual X-ray absorptiometry) does not reflect the complexity of bone pathology in diabetes, which has recently been the subject of debate. Increase in fracture risk is probably related to i.a. disease duration, metabolic disease, presence of complications, type of therapy, the increased susceptibility to falls. The underlying mechanism whereby diabetes type 2 exerts its detrimental effect on bone health is still not clear and often described as poor bone quality. This might be due to the accumulation of advanced glycation end products in bone, abnormal collagen cross-linking, accompanied by low rate of bone turnover. It was also shown that patients with diabetes have impaired structural and geometrical bone parameters. In light of increasing fracture incidence in postmenopausal women, fracture risk calculation is indicated also among older patients with type 2 diabetes. (Diabet. Klin. 2015; 4, 3: 117-126)

Key words: type 2 diabetes, osteoporosis, bone density, osteoporotic fractures, bone turnover 


\section{Wstęp}

Zagadnieniem coraz częściej poruszanym w kontekście przewlekłych powikłań cukrzycy są powikłania kostne, w szczególności złamania niskoenergetyczne. Mimo wzrostu zachorowań na cukrzycę typu 2 w młodszych niż dotychczas grupach wiekowych jej najczęstsza forma, cukrzyca typu 2, ciągle dominuje u ludzi dojrzałych, bardzo często starszych. Statystyki mówią, że w Polsce cukrzycę ma 1/3 osób powyżej 65 . roku życia [1]. W tej samej grupie wiekowej częstym rozpoznaniem jest choroba pozornie niezwiązana z cukrzycą - osteoporoza. Jej główną (często pierwszą) manifestacją kliniczną są złamania - najczęściej trzonów kręgowych, bliższego końca kości udowej, ale także innych miejsc szkieletu (tzw. złamania pozakręgowe). Według raportu International Osteopoorsis Foundation (IOF) na świecie corocznie dochodzi do 8,9 miliona złamań osteoporotycznych, spośród których 30\% stwierdza się w Europie [2]. Mają one istotne implikacje klinicznie - oprócz tego, że zwiększają ryzyko kolejnego złamania, wpływają na skrócenie długości życia - po złamaniu szyjki kości udowej umiera w ciągu roku co 5. kobieta i co 3. mężczyzna, a 50\% chorych traci zdolność do samoobsługi [3]. Szacuje się, że u kobiety w chwili menopauzy prawdopodobieństwo złamania osteoporotycznego $w$ dalszym życiu jest większe (40\%) niż ryzyko zachorowania na raka piersi (14\%), a więc podobne do ryzyka rozwoju choroby niedokrwiennej serca [2].

Robocza definicja osteoporozy opiera się na wyniku badania densytometrycznego (DXA, dual X-ray absorptiometry) wykonanego $w$ obrębie bliższego końca kości udowej lub odcinka lędźwiowego kręgosłupa. Informuje nas ono o mineralnej gęstości kości (BMD, bone mineral density) - kluczowej, ale nie jedynej determinancie wytrzymałości kości. Mineralna gęstość kości określana jest jako T-score - liczba odchyleń standardowych (SD, standard deviation), od których różni się ona od BMD u młodej kobiety w wieku 20-29 lat. Jeśli jest ona o 2,5 SD mniejsza, rozpoznaje się osteoporozę (T-score $<-2,5 \mathrm{SD})$.

W związku z zwiększaniem się średniej długości życia należy spodziewać się coraz większej liczby chorych z rozpoznaniem osteoporozy, ale także cukrzycy - do czego z kolei w największym stopniu przyczynia się siedzący tryb życia, bezruch i oficjalnie uznawana za „epidemię” otyłość. Dane amerykańskie mówią, że największy przyrost w rozpoznawaniu cukrzycy do roku 2050 będzie dotyczył osób powyżej 75. roku życia [4].

\section{Czynniki ryzyka złamania a cukrzyca typu 2}

Fakt pozornie rozbieżnych czynników przyczyniających się do rozwoju obu wymienionych chorób był przyczyną, z powodu której ich nie łączono. W przeciwieństwie do tego cukrzyca typu 1 była i jest uznanym czynnikiem pogarszającym BMD i zwiększającym ryzyko złamania [5]. Pierwsze doniesienia na ten temat datują się na lata 20. XX wieku i w późniejszych latach zostały dobrze udokumentowane. W badaniach wykazano, że chorzy na cukrzycę typu 1 nie osiągają szczytowej masy kostnej podczas okresu dorastania, a to przekłada się na gorszą gęstość mineralną kości i późniejsze częstsze złamania [5-7]. Mechanizmem, który leży u podłoża, jest - oprócz insulinopenii — prawdopodobnie także niskie stężenie insulinopodobnego czynnika wzrostu (IGF-1, insulin-like growth factor 1), działającego anabolicznie na kość [8]. Metaaanaliza Vestergaarda i wsp. pokazała, że ryzyko względne złamania bliższego końca kości udowej u chorych z cukrzycą typu 1 wynosi 6,9 [5].

W opublikowanym w 2001 roku prospektywnym badaniu lowa Women Health Study obejmującym 32 tys. kobiet wykazano, że ryzyko to jest większe w zakresie złamania bliższego końca kości udowej także u chorych na cukrzycę typu 2 [ryzyko względne (RR, relative risk) 1,75 (95\% przedział ufności- $\mathrm{Cl}$, confidence interval 1,25-2,43)] [6]. Podobne wyniki przyniosło Nurses' Health Study oparte na 22-letniej obserwacji, gdzie zauważono także, że czas trwania cukrzycy typu 2 jest istotnym czynnikiem zwiększającym prawdopodobieństwo złamania [dla cukrzycy trwającej ponad 12 lat - RR 2,4 (95\% Cl 1,8-3,1)] [9]. Potwierdziły to późniejsze obserwacje, np. praca Meltona i wsp., którzy udowodnili, że zwiększona częstość złamań bliższego końca kości udowej była widoczna po 10 latach trwania cukrzycy typu 2 [10]. Opublikowane w ostatnich kilku latach metaanalizy rozwiewają wątpliwości - ryzyko niskoenergetycznego złamania bliższego końca kości udowej jest około 1,5-2-krotnie większe w porównaniu z osobami zdrowymi [5, 11]. Najbardziej wzrasta ryzyko złamania bliższego końca kości udowej [11]. Prace niektórych badaczy ujawniły ponadto dodatnią zależność między leczeniem insuliną a ryzykiem złamania $[12,13]$. Nie wydaje się jednak, żeby był to wpływ insuliny per se - jest ona hormonem anabolicznym i tak też działa na kość - ale najprawdopodobniej zaawansowania choroby. Pośrednim dowodem popierającym tę hipotezę jest m.in. praca Nicodemus i wsp., którzy wykazali, że nowo rozpoznana cukrzyca typu 2 zwiększa ryzyko złamania w relatywnie mniejszym stopniu $[R R 1,47,95 \% \mathrm{Cl}$ $(0,81-2,67)]$ niż cukrzyca trwająca ponad 13 lat [RR 2,38, $95 \% \mathrm{Cl}(1,44-3,92)]$ [6]. Również u chorych z prediabetes ryzyko było niższe niż u chorych z leczoną cukrzycą [14].

Hiperglikemia jest czynnikiem, który bezpośrednio może działać hamująco czy wręcz toksycznie na osteoblasty, komórki kościotwórcze. Ma również szereg działań pośrednich, m.in. stymuluje sekrecję interleukiny 6 , 
która działa proresorpcyjnie i — o czym jeszcze będzie mowa - nasila nieezymatyczną glikację kolagenu oraz wpływa najprawdopodobniej hamująco na produkcję jednego z białek kościotwórczych — osteokalcyny [15, 16]. Hiperglikemia może także prowadzić do hiperkalciurii i w ten sposób pogarszać mineralizację kości. Hipokalcemia oceniana wśród chorych na cukrzycę typu 2 może jednak nie wiązać się ze wzrostem stężenia parahormonu (PTH), lecz z jego spadkiem [17], co wpisuje się w szerokie spektrum zaburzeń metabolizmu kostnego u chorych na cukrzycę typu 2.

W piśmiennictwie szeroko dyskutuje się na temat wpływu hipoglikemii - najczęściej związanej z insulinoterapią - na upadki. Upadki jako takie są uważane za jedne z kluczowych problemów pacjentów starszych - należą do tzw. wielkich zespołów geriatrycznych („geriatric giants”). Są to zaburzenia typowe dla osób w wieku podeszłym, będące niespecyficzną manifestacją chorób w starości i prowadzące do stopniowej niesprawności. Złamanie szyjki kości udowej oraz kości promieniowej poprzedzone jest upadkiem w 90\% przypadków, nie dziwi zatem, że jednym z celów leczenia ludzi starszych jest ich unikanie. Udowodniono, że chorzy na cukrzycę w wieku podeszłym upadają częściej niż ich rówieśnicy bez tej choroby. Upadki mogą być także konsekwencją powikłań przewlekłych - neuropatii obwodowej, retinopatii, zespołu stopy cukrzycowej, a także zaawansowanego wieku, hipotonii ortostatycznej, choroby niedokrwiennej serca/mózgu, zmian zwyrodnieniowych stawów i wielu innych przyczyn [18]. Niektórzy autorzy uważają, że osoby z neuropatią cukrzycową częściej doznają upadków na bok niż do przodu/do tyłu [19]. Może to prowadzić do złamań stopy, które rzeczywiście są częściej rejestrowane u chorych na cukrzycę typu 2 niż u osób bez tej choroby [12]. Schwartz i wsp. w badaniu Study of Osteoporotic Fractures (SOF) dowiedli, że upadki u kobiet z cukrzycą typu 2 miały związek z zaburzeniami propriocepcji, niskimi wartościami wskaźnika przesączania kłębuszkowego (GFR, glomerulal filtration rate) oraz pogorszeniem widzenia [20]. Dodatkowy wpływ może mieć typowa dla chorych w wieku podeszłym polipragmazja - upadki wiąże się ze stosowaniem licznych, często przepisywanych starszym pacjentom leków. W pracy Lipscombe i wsp. wykazano, że chorzy na cukrzycę typu 2 w wieku podeszłym są częściej leczeni lekami sprzyjającymi upadkom, m.in. przeciwparkinsonowskimi, przeciwpadaczkowymi, opiatami i innymi [14]. Nie wykazano natomiast, aby inne niż insulina leki przeciwhiperglikemiczne sprzyjały upadkom. Dotyczy to metforminy, która poprzez powodowanie niedoboru witaminy B12 miałaby powodować neuropatię [21], oraz agonistów PPARy (peroxisome proliferator- -activated receptor), które to leki de facto zmieniają mikroarchitekturę kości i zwiększają częstość złamań, ale nie zwiększają ryzyka upadków [22].

Badanie ACCORD BONE - subanaliza badania ACCORD - było pierwszym badaniem randomizowanym, w którym zadano sobie pytanie, czy wyrównanie metaboliczne cukrzycy typu 2 może mieć wpływ na częstość upadków oraz złamań [23]. Zarówno u chorych zakwalifikowanych do leczenia intensywnego [docelowa wartość hemoglobiny glikowanej $\left.\left(\mathrm{HbA}_{1 \mathrm{c}}\right)<6,0 \%\right]$, jak i w ramieniu o "standardowym" wyrównaniu glikemii (docelowa wartość $\mathrm{HbA}_{1 \mathrm{c}} 7,0$ $-7,9 \%)$ częstość upadków nie różniła się statystycznie $(60,8$ vs. 55,3/100 osobolat odpowiednio w ramionach intensywnym i standardowym). Średnia wieku w obu grupach wynosiła 62,5 roku. Zanotowana w 3,5-letniej obserwacji liczba nowych złamań pozakręgowych także była podobna [hazard względny (HR, hazard ratio) między grupami $1,04(95 \% \mathrm{Cl} 0,86-1,27)]$. Zatem mimo że w grupie leczonej intensywnie odnotowano więcej przypadków hipoglikemii (16,2 vs. 5,1\%), nie obserwowano tam zwiększonej liczby upadków i złamań. Autorzy badania wykazali więc, że tzw. intensywna kontrola glikemii w tym zakresie była bezpieczna.

Doniesienia dotyczące związku $\mathrm{HbA}_{1 \mathrm{c}}$ z częstością złamań osteoporotycznych są sprzeczne. Są badacze, według których złamania występują częściej u chorych z wyższym odsetkiem $\mathrm{HbA}_{1 c^{\prime}}$ świadczącym o złym wyrównaniu cukrzycy [24], jak również tacy, którzy notują zjawisko odwrotne - większą częstość złamań przy niższych wartościach $\mathrm{HbA}_{1 c}$ [25]. Docelowy odsetek $\mathrm{HbA}_{1 \mathrm{c}}$ związany z redukcją liczby złamań nie został zatem dotychczas ustalony. Nie wiadomo także, czy istnieje zjawisko „pamięci metabolicznej” w kontekście złamań niskoenergetycznych, a więc, czy prawidłowe wyrównanie glikemii może zmniejszać ryzyko złamania w późniejszym życiu.

\section{Patogeneza zwiększonej lamliwości kości u osób chorych na cukrzycę typu 2}

Najbardziej uderzającą różnicą dotyczącą tkanki kostnej między chorymi na cukrzycę typu 1 a chorymi na cukrzycę typu 2 jest fakt, że w świetle dostępnych badań gęstość masy kostnej u chorych na cukrzycę typu 2 jest taka sama lub wyższa niż u osób zdrowych $[5,26]$. Dotyczy to zarówno bliższego końca kości udowej, jak i kręgosłupa lędźwiowego. Zatem BMD nie tłumaczy zwiększonej łamliwości kości u chorych na cukrzycę typu 2. Uważa się, że u tych chorych upośledzona jest głównie tzw. jakość kości. Nie jest to jednak pojęcie dobrze zdefiniowane.

Zdrowa kość musi być jednocześnie sztywna, a poddana urazowi - zdolna po oporu. Z drugiej strony powinna być na tyle lekka, aby umożliwiać swo- 
Tabela 1. Prawdopodobne czynniki wpływające na zwiększoną łamliwość kości w cukrzycy typu 2

\section{MOLEKULARNE}

Hiperglikemia i stres oksydacyjny

Zaburzenia gospodarki wapniowej i hipowitaminoza D

Niskie tempo obrotu kostnego

Nagromadzenie zaawansowanych produktów glikacji w kości

Zaburzenia układu RANK-RANKL-OPG

Zaburzenia sygnalizacji ścieżki Wnt (podwyższone stężenia sklerostyny)

Negatywny wpływ niektórych adipocytokin

Zwiększona adipogeneza w szpiku kostnym (na niekorzyść osteoblastogenezy)

Gorsza mikroarchitektura kości

\section{KLINICZNE}

Częstsze upadki

Hipoglikemia

Przewlekłe powikłania (m.in. neuropatia, retinopatia)

bodny ruch i absorbować obciążenia nim wywołane. Im większa zawartość mineralna kości, tym większa jej sztywność, a gorsza - elastyczność. Siła kości jest sumą jej masy („ilości”) — pośrednio reprezentowanej przez wartości gęstości mineralnej — oraz jakości. Jakość to konglomerat pewnych parametrów materiałowych kości, które pośrednio informują, jak tkanka szkieletowa opiera się złamaniu. Jest to np. mikroarchitektura beleczek kostnych, tempo obrotu kostnego, geometria kości, wielkość kryształów mineralnych i inne.

Przyczyny gorszej jakości kości u chorych na cukrzycę mogą być wielorakie (tab. 1). Na pierwszym miejscu wymienia się patologię usieciowania kolagenu - głównego składnika macierzy kostnej - w wyniku nagromadzenia zaawansowanych produktów glikacji (AGE, advanced glycation products). Stabilizacja i wiązanie nowo powstałych włókien kolagenowych w kości odbywają się przez tworzenie wiązań kowalencyjnych pomiędzy sąsiadującymi cząsteczkami w procesach modyfikacji posttranslacyjnej. Wiązania te można podzielić na: „korzystne”, regulowane przez oksydazę lizynową, oraz „wadliwe”, nieenzymatyczne, indukowane przez glikację i oksydację w procesie dołączania AGE. Zaawansowane produkty glikacji pogarszają materiałowe właściwości kolagenu, zwiększając sztywność włókien kolagenu oraz zmniejszając ich elastyczność [27]. Niekorzystne działanie AGE na kość obejmuje także prawdopodobnie wpływ na komórki - badania in vitro pokazały, że zmodyfikowany przez AGE kolagen hamuje proliferację i różnicowanie osteoblastów oraz sprzyja ich apoptozie [28]. Obecność AGE zwykle ocenia się za pomocą stężeń pentozydyny w moczu lub surowicy, wykazano, że korelują one z jej zawartością w bioptatach kości [29]. Badania dowiodły, że akumulacja pentozydyny w kości beleczkowej i korowej wiązała się z gorszą wytrzymałością kości [30]. Obserwowano wyższe stężenia pentozydyny w surowicy u osób chorych na cukrzycę typu 2 z przebytymi złamaniami kręgowymi w porównaniu z osobami bez złamań [31]. Yammamoto i wsp. donieśli, że wysokie stężenia pentozydyny i niskie stężenia endogennego receptora dla AGE (esRAGE, endogenous secretory receptor for AGE), wiążącego AGE, były niezależnymi czynnikami ryzyka złamań u Japonek w wieku pomenopauzalnym z cukrzycą [31, 32]. W badaniu Health $A B C$, obejmującym 500 kobiet rasy białej i czarnej z cukrzycą, w średnim wieku 76,3 roku wykazano, że wyższe stężenia pentozydyny w moczu były predyktorem złamania kręgowego [iloraz szans (OR, odds ratio) 5,93; 95\% Cl, 2,08-16,94] w przeciwieństwie do osób bez cukrzycy, w przypadku których takiego związku nie wykazano [33].

Kolejnym postulowanym mechanizmem, który ma brać udział w zaburzeniu mikroarchitektury kości, jest zmiana tempa obrotu kostnego. W organizmie ludzkim następuje ciągła i cykliczna przebudowa kostna — dynamiczna równowaga procesów kościotworzenia (przy udziale osteoblastów) i resorpcji (osteoklasty). U osób dorosłych określamy ją mianem remodelingu kostnego. Dotyczy on zarówno kości zbitej, jak i gąbczastej i odbywa się w tzw. jednostkach przebudowy kości (BMU, basic multicelullar unit). W przebiegu osteoporozy dochodzi do przewagi resorpcji nad tworzeniem kości oraz do przyspieszenia tzw. obrotu kostnego, czyli ilości nowo powstających miejsc przebudowy (BMU) w jednostce czasu. W efekcie ilość tworzonej kości jest mniejsza, a resorbowanej — większa, co skutkuje zwiększoną podatnością kości na mikrouszkodzenia. Nasilenie obrotu kostnego można badać w surowicy krwi za pomocą specyficznych markerów w surowicy krwi lub moczu. Do markerów kościotworzenia zalicza się np. osteokalcynę (OC, osteocalcin), do markerów resorpcji m.in. N-końcowy telopeptyd kolagenu (NTX) oraz fosfatazę kwaśną, a zwłaszcza jeden z jej pięciu izoenzymów oporny na hamowanie winianem (TRAP, tartrate resistant acid phosphatase). W metaanalizie Starup-Linde badającej przebieg metabolizmu kostnego u chorych na cukrzycę typu 2 wykazano, że jego tempo było wolne, ponieważ zarówno stężenia markerów kościotworzenia, jak i resorpcji były niższe niż u osób zdrowych. Ponadto obrót kostny korelował ujemnie z czasem trwania cukrzycy [34]. Nie umiemy do końca wytłumaczyć tego mechanizmu. Niski obrót kostny z zahamowaniem kościotworzenia można zobrazować w badaniu histomorfometrycznym, ale dane na ten temat są bardzo ubogie [35]. Nie jest także jasne, jak 
wyrównanie metaboliczne $\left(\mathrm{HbA}_{1 c}\right)$ cukrzycy wpływa na remodeling, ponieważ wyniki badań w tym zakresie są sprzeczne. Co ciekawe, stężenia izoenzymu kostnego fosfatazy zasadowej, wskazującego na mineralizację kości, były w omawianej metaanalizie prawidłowe lub wysokie [34]. Może to świadczyć o „hipermineralizacji" macierzy kostnej i tłumaczyć paradoks wysokich wartości BMD przy większej podatności na złamania.

Przy okazji obrotu kostnego warto dodać, że szkielet, klasycznie postrzegany jako strukturalne rusztowanie niezbędne do ruchu, regulator gospodarki wapniowo-fosforanowej oraz krwiotworzenia, w ostatnich latach jest opisywany jako organ o aktywności endokrynnej, a nie jedynie punkt docelowy działania hormonów. Za sprawą osteokalcyny (OC) jest potencjalnie ważnym regulatorem płodności męskiej [36], ale przede wszystkim - równowagi energetycznej organizmu. Osteokalcyna jest białkiem składającym się z 46-50 aminokwasów. Ulega ekspresji w dojrzałych osteoblastach, wiąże się z hydroksyapatytem macierzy kostnej, wydzielana jest ponadto do krwi. Cząsteczka OC jest posttranslacyjnie modyfikowana przez witaminę K w miejscu trzech reszt kwasu glutaminowego. Wykazano pierwotnie, że myszy pozbawione genu dla OC nie miały szczególnych defektów szkieletu, były natomiast otyłe i charakteryzowały się hiperglikemią, hipoinsulinemią i zmniejszoną ekspresją genów docelowych dla działania insuliny w wątrobie (Foxa2, Mcad, Nrft itp.) [37]. W późniejszych badaniach udowodniono, że OC wydzielona do krwioobiegu wpływa na metabolizm glukozy dwojako. Poprzez połączenie z receptorem GPRC6 (G-protein coupled receptor) na komórkach beta powoduje wzrost syntezy insuliny. Poprawia także wrażliwość na nią, stymulując termogenezę w brunatnej tkance tłuszczowej, sprzyjając wydatkowaniu energii w mitochondriach mięśni poprzecznie prążkowanych, zmniejszając akumulację triglicerydów w wątrobie oraz najprawdopodobniej wzmacniając produkcję adiponektyny w adipocytach [38, 39]. Liczne prace pokazały, że u ludzi stężenia OC ujemnie korelują ze stężeniem glukozy na czczo, zawartością tkanki tłuszczowej, wskaźnikiem masy ciała (BMI, body mass index), wskaźnikami insulinooporności i $\mathrm{HbA}_{1 \mathrm{c}}$ - u osób zdrowych, ale także chorych na cukrzycę [40, 41]. Diaz-Lopez i wsp. zademonstrowali, że niskie stężenia osteokalcyny były niezależnym czynnikiem zwiększającym prawdopodobieństwo zachorowania na cukrzycę typu 2 [42]. Kolejni badacze udowodnili, że czynnikiem istotnie przyczyniającym się do wzrostu ekspresji OC w osteoblastach oraz sekrecji jej aktywnej formy z kości jest insulina (przy udziale receptora dla insuliny obecnego na powierzchni osteoblastów). Sformułowano zatem pojęcie osi kość-trzustka, pole- gającej na tym, że sygnał z trzustki sprzyja sekrecji OC z osteoblastów, a ta z kolei stymuluje komórki beta do wydzielania insuliny [39]. Osteokalcyna, oprócz tego, że jest jednym z nielicznych białek swoistych dla osteoblastów, posiada zatem cechy hormonu: wydzielana w jednym miejscu ustroju wpływa na funkcjonowanie narządów odległych. Co bardzo ciekawe z klinicznego punktu widzenia, w świetle niskiego tempa obrotu kostnego u chorych na cukrzycę typu 2 badacze poddają dyskusji istotną kwestię, czy u tych chorych także należy leczyć osteoporozę lekami antyresorpcyjnymi, np. bisfosfonianami, hamującymi obrót kostny?

W ostatnich latach badacze poświęcają wiele uwagi faktowi wspólnego pochodzenia adipocytów i osteoblastów w szpiku kostnym z mezenchymalnych komórek progenitorowych (MSCs, mesenchymal stem cells) $[43,44]$. Różnicowanie się tych komórek w kierunku jednej z dwóch linii zależy od wielu czynników działających przeciwstawnie i wpływających na przewagę jednej reprezentacji nad drugą. W interakcjach tych biorą udział liczne, krzyżujące się drogi sygnałowe - do czynników aktywujących osteoblastogenezę należy szlak WNT/ $\beta$-katenina (Wingless-type like signalling) oraz ekspresja czynników transkrypcyjnych Msx2, Runx2 i osterix. Natomiast w kierunku promocji adipogenezy działają receptory PPAR $\gamma$ i członkowie rodziny C/EBP (CCAAT, enhancer binding protein) [45, 46]. Badania eksperymentalne pokazały, że pod wpływem hiperglikemii lub wysokich lokalnych stężeń AGE w szpiku kostnym może nastąpić nasilenie adipogenezy kosztem osteoblastogenezy [47, 48]. Docelowo skutkiem może być zahamowanie kościotworzenia i niska masa kostna. Ostatnio publikowane badania sugerują, że część negatywnego wpływu cukrzycy na tkankę kostną można przypisać właśnie zaburzeniom w drogach sygnałowych szlaku Wnt, w szczególności sklerostynie [49]. Sklerostyna jest białkiem produkowanym przez osteocyty, działającym przez inhibicję omawianego szlaku - kluczowego regulatora rozmaitych procesów komórkowych - embriogenezy, organogenezy, nowotworzenia. Zaburzenia jego rozległej i skomplikowanej sygnalizacji wykazano w licznych patologiach, w tym w cukrzycy i osteoporozie $[50,51]$. W kości sklerostyna konkuruje z klasyczną ścieżką sygnałową Wnt/ $\beta$ -katenina w wiązaniu LRP 5 i -6 (low density lipoprotein receptor related protein), aby zapobiec ich połączeniu z receptorami Frizzled, i na tej drodze hamuje sygnalizację Wnt, osteoblastogenezę i tworzenie nowej kości [52]. W przypadku detekcji bodźca uszkadzającego kość osteocyty hamują wydzielanie sklerostyny, dzięki czemu dochodzi do proliferacji osteoblastów i przewagi kościotworzenia, co ma na celu odbudowę kości po urazie. Zatem inhibicja sklerostyny jest jednym z potencjalnych 
celów terapeutycznych w osteoporozie. Nieliczne badania oceniające tę glikoproteinę u chorych z cukrzycą mówią o jej podwyższonych stężeniach w surowicy, a oprócz tego opisują dodatnią korelację z gęstością mineralną kości, czasem trwania cukrzycy i wartością $\mathrm{HbA}_{1 \mathrm{c}}[51,53]$. Ardawi i wsp. wykazali ponadto w badaniu przekrojowym, że u kobiet chorych na cukrzycę typu 2 podwyższone stężenia sklerostyny wiązały się z częstszymi złamaniami kręgowymi [dla obecności jednego złamania OR = 1,27 (95\% Cl $(1,01-2,03)]$ oraz współistniały z niskim obrotem kostnym [54].

Biorąc pod uwagę wspólne pochodzenie osteoblasta i adipocyta, pole do badania interakcji między masą ciała, tkanką tłuszczową i kostną jest bardzo szerokie. Znaczenie ma aktywność metaboliczna adipocytów, zarówno tych zlokalizowanych w tkance tłuszczowej właściwej, jak i adipocytów szpiku kostnego. Są one miejscem syntezy licznych związków o szerokim biologicznym spektrum działania, w tym o bardzo prawdopodobnym działaniu na tkankę kostną, np. adiponektyny.

Adiponektyna jest hormonem regulującym wrażliwość na insulinę oraz mającym działanie przeciwzapalne. Udowodniono, że jej niskie stężenia w surowicy współistnieją z licznymi patologiami - cukrzycą typu 2 oraz jawną klinicznie miażdżycą, w tym z zawałem serca $[55,56]$. Jej stężenia w surowicy odwrotnie korelują z zawartością tkanki tłuszczowej - u osób otyłych stwierdza się hipoadiponektynemię [57].

Adiponektyna i jej receptory ulegają ekspresji w ludzkich osteoblastach. Jej wpływ na metabolizm tkanki kostnej nie jest jednak jednoznaczny. Badania in vitro pokazały, że białko to sprzyja różnicowaniu komórek prekursorowych do preosteoblastów, a w drugim etapie stymuluje proliferację, dojrzewanie i mineralizację osteoblastów [58]. Inną drogą działania tej adipocytokiny na kość jest jej oddziaływanie na osteoklasty, jednak w świetle dotychczasowych badań nie można jednoznacznie stwierdzić, jaki jest jego kierunek. Istnieją ponadto rozbieżności między wynikami badań in vitro i in vivo - obecnie trudno rozstrzygnąć, czy oddziaływanie adiponektyny netto na kość jest pozytywne czy negatywne. Te rozbieżności tłumaczy się m.in. tym, że stężenie adiponektyny w osoczu może nie odzwierciedlać jej rzeczywistej produkcji w tkance tłuszczowej, a także występowaniem kilku form cząsteczkowych tej glikoproteiny o potencjalnie różnych siłach działania [59]. W większości badań klinicznych wykazano ujemną korelację między stężeniem adiponektyny w osoczu a BMD [60]. Metaanaliza Biver i wsp. obejmująca 59 badań udowodniła, że adiponektyna jest najsilniej ujemnie skojarzoną z BMD adipocytokiną, niezależnie od płci, wieku i zawartości tkanki tłuszczowej [61]. U mężczyzn wysokie osoczowe stężenie adiponektyny okazało się być dobrym predyktorem złamań kręgowych [62].
U chorych na cukrzycę zademonstrowano także podwyższone stężenia osteoprotegeryny (OPG) [63]. Osteoprotegeryna jest częścią jednego z najważniejszych układów w biologii kości - RANK/RANKL/OPG. RANKL — ligand dla receptora aktywującego jądrowy czynnik kappa B (receptor activator of nuclear factor kappa-B ligand) - ulega ekspresji w komórkach zrębu i osteoblastach w mikrośrodowisku szpiku kostnego $[64,65]$. Wiąże się z receptorem sygnałowym (RANK) na powierzchni prekursorów, ale także dojrzałych osteoklastów, w celu ich rekrutacji, różnicowania i stymulacji resorpcji kości [66]. O interakcję z tym samym receptorem jądrowym współzawodniczy OPG, będąca rozpuszczalnym białkowym „receptorem - pułapką”. Po połączeniu RANKL z OPG dochodzi do blokady konkurencyjnego połączenia RANK-RANKL, zahamowania osteoklastogenezy i przewagi kościotworzenia. Stąd względne stężenie RANKL i OPG w kości decyduje o strukturze i wytrzymałości kości, a OPG uważana jest za inhibitor osteoklastogenezy. Liczne prace dotyczące OPG udowadniają jej znaczenie w procesie wapnienia ściany naczyniowej i miażdżycy $[67,68]$, u chorych z cukrzycą pretendują one do miana markera powikłań sercowo-naczyniowych [69, 70]. Badania oceniające związek między OPG a BMD oraz złamaniami wśród chorych na cukrzycę typu 2 są nieliczne. Obecnie brak wystarczających dowodów na to, aby uznać OPG za predyktor lub marker złamań niskoenergetycznych [71].

Liczne dane mówią także o niskich stężeniach witaminy D - ocenianych za pomocą 25(OH)D - u chorych na cukrzycę typu 2. W tym kontekście mowa oczywiście o dobrze udokumentowanym działaniu klasycznym witaminy D, która promuje wbudowanie wapnia w kość i zmniejsza częstość złamań bliższego końca kości udowej u mężczyzn i kobiet po menopauzie. Oprócz tego wiele miejsca w literaturze w ostatnich latach poświęca się licznym pozaszkieletowym działaniom witaminy $D$. Związki łączące witaminę D i metabolizm węglowodanów obejmują m.in. obecność receptora dla witaminy D i ekspresję 1- $\alpha$ hydroksylazy w komórkach $\beta$ trzustki oraz obecność elementu odpowiedzi dla witaminy $D$ (VDRE, vitamin D response element) w regionie promotora ludzkiego genu insuliny [72]. Liczne badania - głównie przekrojowe oraz obserwacyjne - wskazują na zwiększone ryzyko zachorowania na cukrzycę typu 2 związane z hipowitaminozą D. Na przykład w badaniu Framingham Offspring Study obejmującym 3000 osób w obserwacji prospektywnej wykazano, że wyższe stężenia 25(OH)D wiązały się z niższym o 40\% ryzykiem zachorowania na cukrzycę typu 2 [73]. Także badania interwencyjne - choć nie wszystkie - wydają się potwierdzać ten związek. W Nurses' Heath Study [74] badacze pokazali, że podaż 1200 mg wapnia oraz 
1800 jm. cholekalcyferolu była związana z 33-procentową redukcją ryzyka zachorowania na cukrzycę typu 2 w porównaniu z podażą mniejszych dawek. Postulowane działania witaminy D mają zatem zasadniczo obejmować stymulację sekrecji insuliny w komórkach $\beta$, natomiast wpływ na inne parametry (np. nasilenie stanu zapalnego, różnicowania adipocytów czy wpływ na insulinooporność mięśni poprzecznie prążkowanych) jest dyskutowany. U osób chorych na cukrzycę w porównaniu z populacją ogólną zaopatrzenie w witaminę D może być gorsze z powodu otyłości (sekwestracja witaminy rozpuszczalnej w tłuszczach), hiperglikemia hamuje ponadto reabsorpcję wapnia w kanalikach nerkowych. Nie opublikowano natomiast badań, które oceniałyby wpływ suplementacji witaminą D na złamania u chorych na cukrzycę typu 2.

\section{Możliwości oceny jakości tkanki kostnej u chorych na cukrzycę}

Ponieważ tradycyjny pomiar BMD za pomocą dwuwiązkowej absorpcjometrii rentgenowskiej nie wyjaśnia, dlaczego chorzy na cukrzycę typu 2 doznają złamań częściej (masa kostna jest zwykle prawidłowa lub podwyższona), dąży się do oceny struktury kości w inny sposób. Mikroarchitekturę kości można ocenić za pomocą jakościowej tomografii komputerowej o wysokiej rozdzielczości (HR-pQCT, high resolution peripheral quantitative computed tomography). Została ona wprowadzona niedawno jako nieinwazyjna, trójwymiarowa metoda oceny kości szkieletu obwodowego in vivo (dystalna część kości promieniowej i piszczeli). Pozwala ona na analizę BMD tzw. objętościowego (vBMD, volumetric BMD) oddzielnie w kości korowej i beleczkowej. U chorych na cukrzycę typu 2 wartości tych parametrów są podwyższone. Dodatkowo, ze względu na wysoką rozdzielczość, umożliwia ona obliczenie szczegółowych, określonych parametrów mechanicznych, geometrycznych i „mikroarchitektonicznych" obu typów kości (m.in. grubość kości korowej, pole kości korowej, pole kości beleczkowej, liczbę beleczek, sztywność i inne). Badania te dają podstawy do przypuszczeń, że w cukrzycy typu 2 kość beleczkowa ma strukturę prawidłową, a nawet wzmocnioną, a główna patologia dotyczy kości korowej. Ma to znaczenie dlatego, że kość korowa stanowi 80\% szkieletu, lokuje się głównie w miejscach poza kręgosłupem, a tam właśnie dochodzi do największej liczby złamań wśród chorych na cukrzycę. Ciągle nieliczne badania na ten temat [75, 76] wykazały w HR-pQCT zwiększoną porowatość kości korowej w obrębie dystalnej części kości promieniowej oraz piszczelowej u kobiet z cukrzycą po złamaniu, w porównaniu z tymi bez złamania w wywiadzie. Autorzy wykazali natomiast większą grubość kości beleczkowej (trabecular thickness) oraz gęstość mineralną kości beleczkowej (trabecular BMD).

Inne obserwacje wynikają natomiast z badań wykorzystujących analizę wyłącznie kości beleczkowej z użyciem tzw. TBS (trabecular bone score). Jest to metoda stosunkowo nowa. Dostarcza pośredniego opisu mikroarchitektury beleczek kostnych, który jest oparty na analizie gęstości masy kostnej w konwencjonalnym badaniu DXA. TBS można ocenić jednoczasowo, używając dodatkowego oprogramowania przy wykonywaniu DXA z odcinka lędźwiowego kręgosłupa. Niskie wartości TBS $(<1,200)$ mówią o mniejszej ilości gorzej połączonych i rzadziej rozmieszczonych beleczek, podczas gdy wysokie (> 1,350) — o lepszej („gęstszej”) strukturze kości beleczkowej. Duże (29 tys. chorych) kanadyjskie badanie retrospektywne obejmujące lokalny rejestr chorych z osteoporozą pokazało, że TBS było niezależnym predyktorem złamań u chorych z cukrzycą typu 2 [77]. W odróżnieniu od wartości BMD, które były wyższe niż u osób bez cukrzycy, wartości TBS były istotnie niższe.

W piśmiennictwie pojawiły się ponadto doniesienia na temat oceny siły materiałowej kości (BMS, bone material strenght), której można dokonać się za pomocą techniki mikroindentacji (mikrowgłębiania). Jest to eksperymentalna, ale posiadająca badania walidacyjne mikroinwazyjna metoda, która polega na wprowadzeniu sondy do kości piszczelowej przez skórę, odsunięciu okostnej i wykonaniu indentacji (wgięć) przyłożonych z określoną siłą i częstotliwością. Siła nacisku sondy jest niewielka i dla pacjenta odczuwalna minimalnie, ale na tyle duża, że - poprzez indukowanie separacji mineralizowanych włókien kolagenu - powoduje mikropęknięcia w kości. Pewne określone parametry techniczne oceniają siłę/opór, z jaką kość opiera się temu uszkodzeniu. W badaniu Farra i wsp. z Mayo Clinic of Medicine wykazano, że u chorych na cukrzycę typu 2 istotnie niższe były wartości BMS, zarówno surowe, jak i po uwzględnieniu wieku, nadciśnienia, retinopatii, neuropatii, nefropatii i powikłań makronaczyniowych [78]. Przekładało się to na mniejszą twardość kości (o ok. 33\%). Badacze pokładają nadzieję, że ten typ procedury diagnostycznej będzie $\mathrm{w}$ stanie $\mathrm{w}$ pełni wyjaśnić parametry materiałowe kości u chorych na cukrzycę typu 2.

\section{Kalkulacja ryzyka złamania}

Gęstość mineralna kości jest bardzo ważnym, ale nie jedynym elementem, który determinuje jej wytrzymałość. Jak udowodniły badania, podatność na złamania jest konglomeratem wielu czynników klinicznych i wykracza poza wartości badania densytometrycznego.

Aby w sposób prosty wyodrębnić pacjentów najbardziej narażonych na złamania, sformułowano 
tzw. kalkulatory ryzyka złamania. Najważniejszym z nich jest FRAX ${ }^{\mathrm{TM}}$, zalecany do codziennego użytku, opracowany przez ekspertów z Wielkiej Brytanii pod auspicjami Światowej Organizacji Zdrowia - WHO, World Health Organization (http/: www.shef.ac.uk:FRAX). Po wprowadzeniu prostych danych klinicznych (m.in. wieku, płci, BMI, przebytego złamania, złamania bliższego końca kości udowej u rodzica, palenia tytoniu, spożywania alkoholu, przyjmowania steroidów, opcjonalnie wartości BMD z bliższego końca kości udowej) oblicza 10-letnie ryzyko złamania. Jednym z dystaktorów, o które „pyta” FRAX $^{\mathrm{TM}}$, jest pytanie o osteoporozę wtórną, której obecność zwiększa ryzyko. Kwestią dyskutowaną jest natomiast fakt, czy za potencjalną przyczynę osteoporozy wtórnej uznać cukrzycę typu 1 lub 2. Do niedawna uzasadnione było zaliczenie w jej poczet jedynie cukrzycy typu 1. W świetle narastającej liczby danych i udokumentowanego badaniami przekonania, że cukrzyca typu 2 także wiąże się z częstszymi złamaniami, eksperci European Society for Clinical and Economic Ascpects of Osteoporosis and Osteoarthritis (ESCEO) i IOF w najnowszej edycji europejskich wytycznych dotyczących leczenia osteoporozy uznali, że za przyczynę osteoporozy wtórnej należy uznać także cukrzycę typu 2.

Istnieją liczne narodowe wersje FRAX ${ }^{\mathrm{TM}}$, w tym polska, i związane z tym pojęcie tzw. progów terapeutycznych. W każdym z krajów ustalono bowiem, jaka wartość 10-letniego ryzyka złamania upoważnia do włączenia farmakoterapii. W Polsce próg ten to $10 \%$.

Tymczasem dla chorych z cukrzycą typu 2 kalkulacja FRAX ${ }^{\mathrm{TM}}$ wydaje się nie doszacowywać zagrożenia. Schwartz i wsp., analizując kohorty z 3 dużych prospektywnych badań obserwacyjnych (SOF, MrOs i HealthABC), wyciągnęli szereg istotnych wniosków. Po pierwsze, przy takiej samej wartości ryzyka złamania wyliczonej z FRAX kobiety z cukrzycą typu 2 doznawały złamań częściej niż zdrowe; po drugie, takie same wartości FRAX u kobiet z cukrzycą korespondowały z wartościami T-score o 0,5 jednostki wyższymi w porównaniu z T-score u kobiety zdrowej. Innymi słowy, u chorej z cukrzycą i T-score -1,9 SD (zgodnie z kryteriami WHO osteopenia) ryzyko złamania było takie samo jak osoby zdrowej z T-score -2,5 SD [79]. Analogiczne wnioski wyciągnięto w odniesieniu do mężczyzn. Spostrzeżenia te potwierdzili także Giangregorio i wsp. na podstawie Canadian Manitoba Bone Density Program, udowadniając jednocześnie, że cukrzyca typu 2 jest niezależnym czynnikiem ryzyka złamania i powinna być włączona do estymacji ryzyka złamania [80].

\section{Wnioski}

Mimo częstej u chorych na cukrzycę typu 2 otyłości oraz prawidłowej lub nawet wyższej niż u osób zdro- wych gęstości mineralnej kości obserwuje się wśród nich zwiększoną podatność na złamania niskoenergetyczne. Jest to szczególnie widoczne po długim okresie trwania choroby. Odpowiada za to prawdopodobnie wiele czynników - podlegająca nieprawidłowej glikacji substancja międzykomórkowa kości, niskie tempo obrotu kostnego, nieprawidłowości mikroarchitektoniczne w kości korowej czy niedobór witaminy D. Dane na ten temat są ciągle fragmentaryczne, ale wydaje się, że związek między cukrzycą typu 2 i złamaniami niskoenergetycznymi jest przez klinicystów niedoceniany.

W świetle alarmujących prognoz dotyczących cukrzycy typu 2 oraz częstości poważnych złamań osteoporotycznych u osób w wieku podeszłym poznanie wspólnych mechanizmów może okazać się bardzo cenne. Nie należy zatem zaniedbywać profilaktyki złamań i pamiętać o prostej kalkulacji ich ryzyka. Wobec istniejących w Polsce zaleceń [81] obowiązuje suplementacja cholekalcyferolu (800-2000 jm./dobę, u osób otyłych dawki większe) oraz ciągłe przypominanie chorym o potrzebie ruchu - korzystnym zarówno dla układu kostnego, jak i niezbędnym w leczeniu cukrzycy.

\section{PIŚMIENNICTWO}

1. Zalecenia kliniczne dotyczące postępowania u chorych na cukrzycę, Diabetologia Kliniczna 2015; 4 (supl. A): A51.

2. Kanis J.A., McCloskey E.V., Johansson H., Cooper C., Rizzoli R., Reginster J.Y. Scientific Advisory Board of the European Society for Clinical and Economic Aspects of Osteoporosis and Osteoarthritis (ESCEO) and the Committee of Scientific Advisors of the International Osteoporosis Foundation (IOF). European guidance for the diagnosis and management of osteoporosis in postmenopausal women. Osteoporos. Int. 2013; 24: 23-57.

3. Magaziner J., Fredman L., Hawkes W. i wsp. Changes in functional status attributable to hip fracture: a comparison of hip fractures patients to community-the dwelling aged. Am. J. Epidemiol. 2003; 157: 1023-1031.

4. Boyle J.P., Honeycutt A.A., Narayan K.M. i wsp. Projection of diabetes burden through 2050: impact of changing demography and disease prevalence in the U.S. Diabetes Care 2001; 24: 1936-1940.

5. Vestergaard P. Discrepancies in bone mineral density and fracture risk in patients with type 1 and type 2 diabetes - a meta-analysis. Osteoporos. Int. 2007; 18: 427-444.

6. Nicodemus K.K., Folsom A.R.; lowa Women's Health Study. Type 1 and type 2 diabetes and incident hip fractures in postmenopausal women. Diabetes Care 2001; 24: 1192-1197.

7. Hofbauer L.C., Brueck C.C., Singh S.K., Dobnig H. Osteoporosis in patients with diabetes mellitus. J. Bone Miner. Res. 2007; 22: 1317-1328.

8. Mastrandrea L.D., Wactawski-Wende J., Donahue R.P. i wsp. Young women with type 1 diabetes have lower bone mineral density that persists over time. Diabetes Care 2008; 31: 1729-1735.

9. Kemink S.A., Hermus A.R., Swinkels L.M. i wsp. Osteopenia in insulin-dependent diabetes mellitus; prevalence and aspects of pathophysiology. J. Endocrinol. Invest. 2000; 23: 295-303.

10. Janghorbani M., Feskanich D., Willett W.C., Hu F. Prospective study of diabetes and risk of hip fracture: the Nurses' Health Study. Diabetes Care 2006; 29: 1573-578.

11. Melton III L.J., Leibson C.L., Achenbach S.J., Therneau T.M., Khosla S. Fracture risk in type 2 diabetes: update of a population-based study. J. Bone Miner. Res. 2008; 23: 1334-1342. 
12. Janghorbani M., Van Dam R.M., Willett W.C., Hu F.B. Systematic review of type 1 and type 2 diabetes mellitus and risk of fracture. Am. J. Epidemiol. 2007; 166: 495-505.

13. Schwartz A., Sellmeyer D., Kristine E. i wsp. Older women with diabetes have anincreased risk of fracture: a Prospective Study. J. Clin. Endocrinol. Metab. 2001; 86: 32-38.

14. de Liefde I.I., van der Klift M., de Laet C.E., van Daele P.L., Hofman A., Pols H.A. Bone mineral density and fracture risk in type 2 diabetes mellitus: the Rotterdam Study. Osteoporos. Int. 2005; 16: 1713-1720.

15. Li Y., Bäckesjö C.M., Haldosén L.A., Lindgren U. IL-6 receptor expression and IL- 6 effects change during osteoblast differentiation. Cytokine 2008; 43: 165-173.

16. Kanazawa I., Yamaguchi T., Yamamoto M. i wsp. Serum osteocalcin level is associated with glucose metabolism and atherosclerosis parameters in type 2 diabetes mellitus. J. Clin. Endocrinol. Metab. 2009; 94: 45-49.

17. Lipscombe L.L., Jamal S.A., Booth G.L., Hawker G.A. The risk of hip fractures in older individuals with diabetes: a population-based study. Diabetes Care 2007; 30: 835-841.

18. Dede A.D., Tournis S., Dontas I., Trovas G. Type 2 diabetes mellitus and fracture risk. Metabolism 2014; 63: 1480-1490.

19. Gregg E.W., Pereira M.A., Caspersen C.J. Physical activity, falls, and fractures among older adults: a review of the epidemiologic evidence. J. Am. Geriatr. Soc. 2000; 48: 883-893.

20. Khazai N.B., Beck G.R. Jr, Umpierrez G.E. Diabetes and fractures: an overshadowed association. Curr. Opin. Endocrinol. Diabetes Obes. 2009; 16: 435-445.

21. Schwartz A.V., Vittinghoff E., Sellmeyer D. i wsp. Health, Aging, and Body Composition Study Diabetes - related complications, glycemic control, and falls in older adults. Diabetes Care 2008; 31: 391-396.

22. Berlie H.D., Garwood C.L. Diabetes medications related to an increased risk of falls and fall-related morbidity in the elderly. Ann. Pharmacother. 2010; 44: 712-717.

23. Kahn S.E., Zinman B., Lachin J.M. i wsp. Rosiglitazone-associated fractures in type 2 diabetes: an Analysis from A Diabetes Outcome Progression Trial (ADOPT); Diabetes Outcome Progression Trial (ADOPT) Study Group. Diabetes Care 2008; 31: 845-851.

24. Schwartz A.V., Margolis K.L., Sellmeyer D.E. i wsp. Intensive glycemic control is not associated with fractures or falls in the ACCORD randomized trial. Diabetes Care 2012; 35: 1525-1531.

25. Kanazawa I., Yamaguchi T., Yamamoto M., Sugimoto T. i wsp. Relationship between treatments with insulin and oral hypoglycemic agents versus the presence of vertebral fractures in type 2 diabetes mellitus. J. Bone Miner. Metab. 2010; 28: 554-560.

26. Oei L., Zillikens M.C., Dehghan A. i wsp. High bone mineral density and fracture risk in type 2 diabetes as skeletal complications of inadequate glucose control: the Rotterdam Study. Diabetes Care 2013; 36: 1619-1628.

27. Ma L., Oei L., Jiang L. i wsp. Association between bone mineral density and type 2 diabetes mellitus: a meta-analysis of observational studies. Eur. J. Epidemiol. 2012; 27: 319-332.

28. Okazaki K., Yamaguchi T., Tanaka K. i wsp. Advanced glycation end products (AGEs), but not high glucose, inhibit the osteoblastic differentiation of mouse stromal ST2 cells through the suppression of osterix expression, and inhibit cell growth and increasing cell apoptosis. Calcif. Tissue. Int. 2012; 91: 286-296.

29. Odetti P., Rossi S., Monacelli F. i wsp. Advanced glycation end products and bone loss during aging. Ann. N.Y. Acad. Sci. 2005; 1043: 710-717.

30. Viguet-Carrin S., Roux J.P., Arlot M.E. i wsp. Contribution of the advanced glycation end product pentosidine and of maturation of type I collagen to compressive biomechanical properties of human lumbar vertebrae. Bone 2006; 39: 1073-1079.

31. Yamamoto M., Yamaguchi T., Yamauchi M., Sugimoto T. Low serum level of the endogenous secretory receptor for advanced glycation end products (esRAGE) is a risk factor for prevalent vertebral fractures independent of bone mineral density in patients with type 2 diabetes. Diabetes Care 2009; 32: 2263-2268.

32. Yamamoto M., Yamaguchi T., Yamauchi M., Yano S., Sugimoto T. Serum pentosidine levels are positively associated with the presence of vertebral fractures in postmenopausal women with type 2 diabetes. J. Clin. Endocrinol. Metab. 2008; 93: 1013-1019.

33. Schwartz A.V., Garnero P., Hillier T.A. i wsp. Pentosidine and increased fracture risk in older adults with type 2 diabetes. J. Clin. Endocrinol. Metab. 2009; 94: 2380-2386.

34. Starup-Linde J., Vestergaard P. Biochemical bone turnover markers in diabetes mellitus. A systematic review. Bone 2015. dostęp 23.03.2015.

35. Krakauer J.C., McKenna M.J., Buderer N.F., Rao D.S., Whitehouse F.W., Parfitt A.M. Bone loss and bone turnover in diabetes. Diabetes 1995; 44: 775-782.

36. Karsenty G. Broadening the role of osteocalcin in Leydig cells. Endocrinology 2014; 155: 4115-4116.

37. Lee N.K., Sowa H., Hinoi E. i wsp. Endocrine regulation of energy metabolism by the skeleton. Cell 2007; 130: 456-469.

38. Ferron M., Hinoi E., Karsenty G., Ducy P. Osteocalcin differentially regulates beta cell and adipocyte gene expression and affects the development of metabolic diseases in wild-type mice. Proc. Natl. Acad. Sci. USA 2008; 105: 5266-5270.

39. Pi M., Quarles L.D. Novel bone endocrine networks integrating mineral and energy metabolism. Curr. Osteoporos. Rep. 2013; 11: 391-399.

40. Pittas A.G., Harris S.S., Eliades M., Stark P., Dawson-Hughes B. Association between serum osteocalcin and markers of metabolic phenotype. J. Clin. Endocrinol. Metab. 2009; 94: 827-832.

41. Motyl K.J., McCabe L.R., Schwartz A.V. Bone and glucose metabolism: a two-way street. Arch. Biochem. Biophys. 2010; 503: 2-10.

42. Díaz-López A., Bulló M., Juanola-Falgarona M. i wsp. Reduced serum concentrations of carboxylated and undercarboxylated osteocalcin are associated with risk of developing type 2 diabetes mellitus in a high cardiovascular risk population: a nested case-control study. J. Clin. Endocrinol. Metab. 2013; 98: 4524-4531.

43. Bianco P., Riminucci M., Gronthos S., Robey P.G. Bone marrow stromal stem cells: nature, biology, and potential applications. Stem Cells 2001, 19: 180-192.

44. Gimble J.M., Robinson C.E., Wu X., Kelly K.A. The function of adipocytes in the bone marrow stroma: an update. Bone 1996; 19: 421-428.

45. Akune T., Ohba S., Kamekura S. i wsp. PPAR gamma insufficiency enhances osteogenesis through osteoblast formation from bone marrow progenitors. J. Clin. Invest. 2004; 113: 846-855.

46. Yoon W.J., Cho Y.D., Kim W.J. i wsp. Prolyl isomerase Pin1-mediated conformational change and subnuclear focal accumulation of Runx2 are crucial for fibroblast growth factor 2 (FGF2)-induced osteoblast differentiation. J. Biol. Chem. 2014; 289: 8828-8838.

47. Yamamoto M., Yamauchi M., Sugimoto T. Elevated sclerostin levels are associated with vertebral fractures in patients with type 2 diabetes mellitus. J. Clin. Endocrinol. Metab. 2013; 98: 4030-4037.

48. Kume S., Kato S., Yamagishi S. i wsp. Advanced glycation end-products attenuate human mesenchymal stem cells and prevent cognate differentiation into adipose tissue, cartilage, and bone. J. Bone Miner. Res. 2005; 20: 1647-1658.

49. Miyata T., Notoya K., Yoshida K. i wsp. Advanced glycation end products enhance osteoclast induced bone resorption in cultured mouse unfractionated bone cells and in rats implanted subcutaneously with devitalized bone particles. J. Am. Soc. Nephrol. 1997; 8: 260-270.

50. Ip W., Chiang Y.T., Jin T. The involvement of the Wnt signaling pathway and TCF7L2 in diabetes mellitus: The current understanding, dispute, and perspective. Cell Biosci. 2012; 2: 28.

51. Papapoulos S.E. Inhibition of sclerostin in the management of osteoporosis: results of a phase 2 clinical trial meet expectations. Bonekey Rep. 2014; 3: 523. 
52. Garcia-Martin A., Rozas-Moreno P., Reyes-Garcia R. i wsp. Circulating levels of sclerostin are increased in patients with type 2 diabetes mellitus. J. Clin. Endocrinol. Metab. 2012; 97: 234-241.

53. Li X., Zhang Y., Kang H. i wsp. Sclerostin binds to LRP5/6 and antagonizes canonical Wnt signaling. J. Biol. Chem. 2005; 280: 19883-19887.

54. Gennari L., Merlotti D., Valenti R. i wsp. Circulating sclerostin levels and bone turnover in type 1 and type 2 diabetes. J. Clin. Endocrinol. Metab. 2012; 97: 1737-1744.

55. Ardawi M.S., Akhbar D.H., Alshaikh A. i wsp. Increased serum sclerostin and decreased serum IGF-1 are associated with vertebral fractures among postmenopausal women with type-2 diabetes. Bone 2013; 56: 355-362.

56. Reinstadler S.J., Klug G., Feistritzer H.J. i wsp. Relation of plasma adiponectin levels and aortic stiffness after acute ST-segment elevation myocardial infarction. Eur. Heart J. Acute. Cardiovasc. Care 2014; 3: 10-17.

57. Lindberg S., Pedersen S.H., Møgelvang R. i wsp. Usefulness of adiponectin as a predictor of all cause mortality in patients with ST-segment elevation myocardial infarction treated with primary percutaneous coronary intervention. Am. J. Cardiol. 2012; 109: 492-496.

58. Weyer C., Funahashi T., Tanaka S. i wsp. Hypoadiponectinemia in obesity and type 2 diabetes: close association with insulin resistance and hyperinsulinemia. J. Clin. Endocrinol. Metab. 2001; 86: 1930-1935

59. Berner H.S., Lyngstadaas S.P., Spahr A. i wsp. Adiponectin and its receptors are expressed in bone-forming cells. Bone 2004; 35: 842-849.

60. Pajvani U.B., Du X., Combs T.P. i wsp. Structure-function studies of the adipocyte-secreted hormone Acrp3/adiponectin. Implications for metabolic regulation and bioactivity. J. Biol. Chem. 2003; 278: 9073-9085.

61. Richards J.B., Valdes A.M., Burling K., Perks U.C., Spector T.D. Serum adiponectin and bone mineral density in women. J. Clin Endocrinol. Metab. 2007; 92: 1517-1523.

62. Jürimäe J., Jürimäe T. Plasma adiponectin concentration in healthy pre- and postmenopausal women: relationship with body composition, bone mineral, and metabolic variables. Am. J. Phys. 2007; 293: E42-E47.

63. Biver E., Salliot C., Combescure C. i wsp. Influence of adipokines and ghrelin on bone mineral density and fracture risk: a systematic review and meta-analysis. J. Clin. Endocrinol. Metab. 2011; 96: 2703-2713.

64. Johansson H., Odén A., Lerner U.H. i wsp. High serum adiponectin predicts incident fractures in elderly men: Osteoporotic fractures in men (MrOS) Sweden. J. Bone Miner. Res. 2012; 27: 1390.

65. Darnay B.G., Haridas V., Ni J., Moore P.A., Aggarwal B.B. Characterization of the intracellular domain of receptor activator of NF-kappaB (RANK). Interaction with tumor necrosis factor receptor-associated factors and activation of NF-kappa $b$ and c-Jun N-terminal kinase. J. Biol. Chem. 1998; 273: 20551-20555.

66. Kartsogiannis V., Zhou H., Horwood N.J. i wsp. Localization of RANKL (receptor activator of NF kappa B ligand) mRNA and protein in skeletal and extraskeletal tissues. Bone 1999; 25: 525-534.

67. Shalhoub V., Faust J., Boyle W.J. i wsp. Osteoprotegerin and osteoprotegerin ligand effects on osteoclasts formation from human peripheral blood mononuclear cell precursors. J. Cell Biochem. 1999; 72: 251-261.

68. Browner W.S., Lui L.Y., Cummings S.R. Associations of serum osteoprotegerin levels with diabetes, stroke, bone density, fractures, and mortality in elderly women. J. Clin. Endocrinol. Metab. 2001; 86: 631-637.

69. Venuraju S.M., Yerramasu A., Corder R., Lahiri A. Osteoprotegerin as a predictor of coronary artery disease and cardiovascular mortality and morbidity. J. Am. Coll. Cardiol. 2010; 55: 2049-2061.

70. Bjerre M. Osteoprotegerin (OPG) as a biomarker for diabetic cardiovascular complications. Springerplus 2013; 2: 658.

71. Nybo M., Rasmussen L.M. The capability of plasma osteoprotegerin as a predictor of cardiovascular disease: a systematic literature review. Eur. J. Endocrinol. 2008; 159: 603-608.

72. Rozas Moreno P., Reyes García R., García-Martín A., Varsavsky M., García-Salcedo J.A., Muñoz-Torres M. Serum osteoprotegerin: bone or cardiovascular marker in type 2 diabetes males? J. Endocrinol. Invest. 2013; 36: 16-20.

73. d Maestro B., Dávila N., Carranza M.C., Calle C. Identification of a Vitamin D response element in the human insulin receptor gene promoter. J. Steroid Biochem. Mol. Biol. 2003; 84: 223-230.

74. Liu E., Meigs J.B., Pittas A.G. i wsp. Predicted 25-hydroxyvitamin D score and incident type 2 diabetes in the Framingham Offspring Study. Am. J. Clin. Nutr. 2010; 91: 1627-1633.

75. Liu S., Song Y., Ford E.S., Manson J.E., Buring J.E., Ridker P.M. Dietary calcium, vitamin D, and the prevalence of metabolic syndrome in middle-aged and older US women. Diabetes Care 2005; 28: 2926-2932.

76. Burghardt A.J., Issever A.S., Schwartz A.V. i wsp. High-resolution peripheralquantitative computed tomographic imaging of cortical and trabecular bonemicroarchitecture in patients with type 2 diabetes mellitus. J. Clin. Endocrinol. Metab. 2010; 95: 5045-5055.

77. Patsch J.M., Burghardt A.J., Yap S.P., Baum T., Schwartz A.V., Joseph G.B., Link T.M. Increased cortical porosity in type 2 diabetic postmenopausal women with fragility fractures. J. Bone Miner. Res. 2013; 28: 313-324.

78. Leslie W.D., Aubry-Rozier B., Lamy O., Hans D. TBS (trabecular bone score) and diabetes-related fracture risk. J. Clin. Endocrinol. Metab. 2013; 98, 602-609.

79. Farr J.N., Drake M.T., Amin S., Melton $\sqcup$ 3rd, McCready L.K., Khosla S. In vivo assessment of bone quality in postmenopausal women with type 2 diabetes. J. Bone Miner. Res. 2014; 29: 787-795.

80. Schwartz A.V., Vittinghoff E., Bauer D.C. i wsp. Study of Osteoporotic Fractures (SOF) Research Group; Osteoporotic Fractures in Men (MrOS) Research Group; Health, Aging, and Body Composition (Health $A B C$ ) Research Group. Association of BMD and FRAX score with risk of fracture in older adults with type 2 diabetes. JAMA 2011; 305: 2184-2192.

81. Giangregorio L.M., Leslie W.D., Lix L.M. i wsp. FRAX underestimates fracture risk in patients with diabetes. J. Bone Miner. Res. 2012; 27: 301-308.

82. Płudowski P., Karczmarewicz E., Bayer M. i wsp. Practical guidelines for the supplementation of vitamin $D$ and the treatment of deficits in Central Europe - recommended vitamin D intakes in the general population and groups at risk of vitamin D deficiency. Endokrynol. Pol. 2013; 64: 319-327. 